is therefore most likely that the thiophosphorylation of the $70 \mathrm{~K}$ protein affects a pre-catalytic step of the splicing reaction.

Our data show that the $70 \mathrm{~K}$ protein is important for the splicing reaction in vitro and, moreover, that its function depends critically upon the way in which it is phosphorylated. But the molecular basis of the inhibition of splicing by thiophosphorylation of the $70 \mathrm{~K}$ protein is unclear. It may be that the $70 \mathrm{~K}$ protein has to undergo a phosphorylation-dephosphorylation cycle during its action in the spliceosome. This cycle would be blocked by the failure of phosphatases to release the phosphorothioate thiophosphorylated groups from the $70 \mathrm{~K}$ protein. This idea seems attractive and is supported by the finding that highly specific inhibitors (okadaic acid, tautomycin and microcystin-LR) of protein phosphatases PrP1 and PrP2a differentially inhibit the two catalytic steps of mammalian pre-mRNA splicing ${ }^{14,15}$. Inhibition of $\mathrm{PrP} 2 \mathrm{a}$ predominantly inhibits the second catalytic step of splicing ${ }^{14}$, whereas inhibition of PrP1 and PrP2a affects both splicing steps ${ }^{15}$. A form of PrP1 could be a good candidate for the phosphatase involved in U1 $70 \mathrm{~K}$ dephosphorylation. In addition, and this may not be mutually exclusive, the phosphate groups could function as part of a recognition site on the $70 \mathrm{~K}$ protein for other spliceosomal factors; this recognition would be disturbed if the normal phosphate were replaced by a phosphorothioate group.

The kinase activity associated with the U1 snRNP selectively phosphorylates the arginine/serine rich domains ( $R / S$ domains) in the $\mathrm{C}$-terminal half of the $70 \mathrm{~K}$ protein (our unpublished results). Interestingly, $\mathrm{R} / \mathrm{S}$ domains have also been found in many metazoan non-snRNP splicing factors ${ }^{16-22}$. Preliminary evidence indicates that other splicing factors containing $\mathrm{R} / \mathrm{S}$ domain (such as SF-2 and U2AF) are also phosphorylated ${ }^{16,19,20}$. Investigation of the importance of phosphorylation in the function of the $\mathrm{U} 170 \mathrm{~K}$ protein should eventually provide us with information on the role of the $\mathrm{R} / \mathrm{S}$ domains of other splicing factors. Furthermore, as U1 snRNPs and the aforementioned splicing factors are involved in the regulation of alternative splicing ${ }^{17-20}$, their post-translational phosphorylation may finely tune the splicing reaction.

Received 3 September 1992; accepted 17 February 1993

1. Steitz, J. A., Black, D. A., Gerke, V. \& Parker, K. A. in Structure and Function of Major and Minor snRNPS 115-154 (Springer, Berlin, 1988).

2. Lührmann, R., Kastner, B. \& Bach, M. Biochim. biophys. Acta 1087, 265-292 (1990),

3. Green, M. R. A. Rev. Cell Biol. 7, 559-599 (1991)

4. Ruby, S. W. \& Abelson, J. Trends Genet. 7, 79-85 (1991).

5. Guthrie, C. Science 253, 157-163 (1991).

6. Rymond, B. C. \& Rosbash, M. in The Molecular and Cellular Biology of the Yeast Saccharomyces (Cold Spring Harbor Laboratory Press, New York, 1992).

7. Michaud, S. \& Reed, R. Genes Dev. 5, 2534-2546 (1991).

8. Jamison, S. F. \& Garcia-Blanco, M. A. Proc, natn. Acad. Sci. U.S. A. 89, 5482-5486 (1992)

9. Tatei, K. Takemura, K., Tanaka, H., Masaki, T. \& Hoshima, V. J. biol. Chem. 262, 11667-11674 (1987).

10. Heinrichs, V., Bach, M., Winkelmann, G. \& Lührmann, R. Science 247, 69-72 (1990).

11. Wooley, J. C., Zuckerberg, L. R. \& Chung, S. Y. Proc. natn. Acad. Sci. U.S. A. 80, 5208-5212 (1983),

12. Woppmann, A., Patschinsky, T., Bringmann, P., Godt, F. \& Lührmann, R. Nucleic Acids Res. 18, 4427-4438 (1990)

13. Khelli, S., Daugeron, M. C., Alibert, C., Jeanteur, P., Cathala, G. \& Brunel, C. Nucleic Acids Res. 19, 877-884 (1991).

14. Tazi, J., Daugeron, M. C., Cathala, G., Brunel, C. \& Jeanteur, P. J. biol. Chem. 267, 4322-4326 (1992).

15. Mermoud, J. E., Cohen, P. \& Lamond, A. I. Nucleic Acids Res. 20, 5263-5269 (1992).

16. Zamore, P. D., Patton, J. G. \& Green, M. R. Nature 355, 609-614 (1992).

17. Amrein, H., Gorman, M. \& Nothiger, R. Cell 55, 1025-1035 (1988).

18. Goralski, T. J., Edstrom, J. E. \& Baker, B. S. Cell 56, 1011-1018 (1989).

19. Ge, H., Zuo. P. \& Manley, J. L. Cell 66, 373-382 (1991).

20. Krainer, A. R., Mayeda, A., Kozak, D. \& Binns, G. Cell 66, 383-394 (1991).

21. Fu, X. D. \& Maniatis, T. Science 256, 535-538 (1992).

22. Zahler, A. M., Lane, W. S., Stolk, J. A. \& Roth, M. B. Genes Dev. 6, 837-847 (1992)

23. Bach, M., Bringmann, P. \& Lührmann, R. Meth. Enzym. 181, 232-256 (1990).

24. Dignam, J. D., Lebovitz, R. M. \& Roeder, R. G. Nucleic Acids Res. 11, 1475-1489 (1983)

25. Lelay-Taha, M. N., Reveillaud, I., Sri-Wridada, J., Brunel, C. \& Jeanteur, P. J. molec. Biol. 189, 519-539 (1986).

26. Habets, W. J., Hoet, M. H., De Jong, B. A. W., van der Kemp, A. \& van Venrooij, W. J. J. Immun. 143, 2560-2566 (1989)

27. Tazi, J., Forné, T., Jeanteur, P., Cathala, G. \& Brunel, C. Molec, cell. Biol. (in the press)

28. Blencowe, B. J., Sproat, B. S., Ryder, U., Barabino, S. \& Lamaond, A. I. Cell 59, 531-539 (1989).

29. Nelson, K. K. \& Green, M. R. Genes Dev. 2, 319-329 (1988).

ACKNOWLEDGEMENTS. We thank I. Öchsner-Welpelo, S. Brner and R. Dietz for technical assistance. This work was supported by grants from the Deutsche Forschungsgemeinschaft and the Fonds der Chemischen Industrie (R.L.) and from the Centre National de la Recherche Scientifique, the Association pour la Recherche contre le Cancer and the University of Montpellier II (C.B.).
ERRATA

\section{Three-dimensional cryo-electron microscopy of the calcium ion pump in the sarcoplasmic reticulum membrane}

\author{
Chikashi Toyoshima, Hiroyuki Sasabe \\ \& David L. Stokes
}

Nature 362, 469-471 (1993)

FIGURE $1 c$ was omitted from the above letter during the production process and is now shown below.

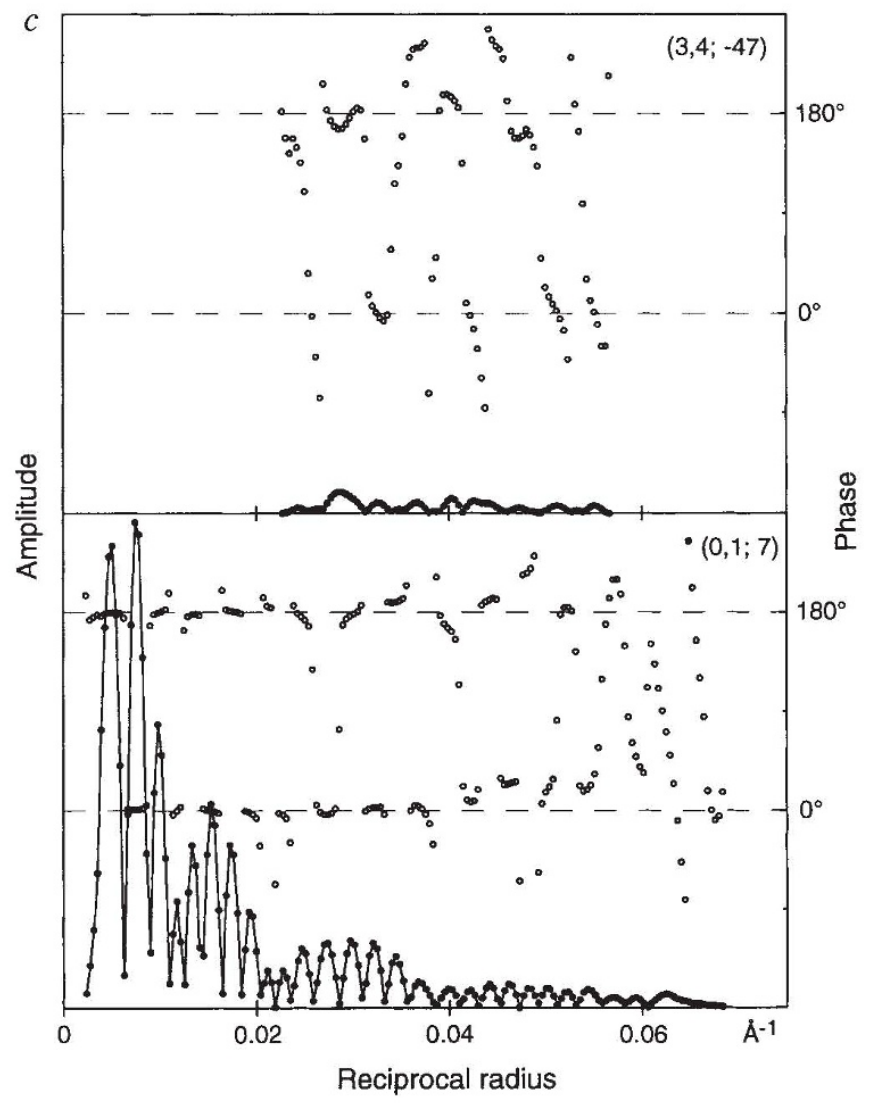

In addition, part of the label at the bottom left-hand corner of Fig. $4 a$ was unclear. This should read 'A2(M6, M8)'.

\section{Dispersion of neural progenitors within the germinal zones of the forebrain}

\author{
Gord Fishell, Carol A. Mason \& Mary E. Hatten
}

Nature 362, 636-642 (1993)

THE date of receipt of this letter was erroneously given as 14 December 1992 instead of 2 September 1992. 